\title{
CHROMOSOME NUMBERS OF SOME ANGIOSPERMS FROM THE SOUTH OF FRANCE
}

\author{
E. KLIPHUIS \\ Instituut voor Systematische Plantkunde, afdeling Biosystematiek, Utrecht
}

\section{J. H. WIEFFERING}

Laboratorium voor Experimentele Plantensystematiek, Leiden

\section{SUMMARY}

The chromosome number of $\mathbf{4 2}$ plant species collected in the wild in the South of France has been determined. Notes on some species are given.

\section{INTRODUCTION}

The flora of the Mediterranean region has been much less investigated in cytological respect than that of North-Western Europe.

For a good understanding of the cytogeography of a given species it is necessary to carry out extensive investigations throughout its entire area. Recent studies have often revealed the occurrence of different chromosome numbers within one species, and sometimes it appeared to be difficult to find a clear correlation between differences in morphology and/or ecological preferences. The only way to solve these problems is to study a very large number of plants taken from as many localities as possible. This is the background against which investigations on a number of plants from the Mediterranean region were carried out, the results of which are given below.

In such investigations only counts are valuable for which there is welldocumented voucher material. Therefore, in nature both plants for the herbarium and seeds were collected. The herbarium specimens collected in the wild by the junior author have been deposited in the herbarium of the Laboratorium voor Experimentele Plantensystematiek at Leiden. The seeds were germinated in the experimental garden of the University of Utrecht. The plants thus obtained were examined cytologically and subsequently preserved in the herbarium of Utrecht $(\mathrm{U})$ where the microscopical slides are also kept.

\section{MATERIAL AND METHODS}

The seeds collected were sown in the experimental field of the Botanical Garden of the State University of Utrecht. The seedlings were potted and from this material roottips were fixed in Karpechenko's fixative, embedded in paraffinewax, sectioned at $15 \mu$, and stained according to Heidenhain's haematoxylin method. 
In two cases (Galeopsis reuteri Reichenb. and Lamium maculatum $\mathrm{L}$.) the chromosome number was determined from material fixed in the field. For this purpose flowerbuds were fixed in Carnoy's fixative, squashed, and stained with aceto-carmine.

\section{RESULTS}

The results of the chromosome counts are given in the following table. This table gives a survey of the species investigated, the source of the material, and the collection number. The first number listed represents the herbarium material collected in the wild (L.E.P.), the second the material cultivated in the experimental garden. Notes on some species, marked with a plus sign $\left({ }^{+}\right)$, are added.

\section{NOTES ON SOME SPECIES}

\section{$1^{+}$Amaranthus deflexus $\mathrm{L}$.}

The chromosome number $2 \mathrm{n}=34$ for this species is also known from the studies in the Amaranthaceae by GrANT (1959). Three out of the four counts given by him are from plants cultivated from seeds received from botanical gardens. The origin of this material is unknown. The fourth count refers to material collected in the wild in Oklahoma, U.S.A. In the chromosome portraits of Amaranthus deflexus as given by Grant two satellites are present. Such satellites could not be observed in our material.

\section{$4^{+}$Silene nutans L. subsp. dubia (Herbich) Zapal.}

In Flora Europaea Silene nutans is subdivided into two subspecies. Subspecies dubia is characterized by: inflorescence branches usually 1- to 3-flowered, calyx teeth usually unequal, petal claw $2,4-4,5 \mathrm{~mm}$, with a well-developed auricle, and capsule 4-5 times as long as the carpophore. These characters completely agree with our material. The chromosome number of this subspecies was not known; it turned out to be $2 \mathrm{n}=24$, the most common chromosome number in European Silenes.

\section{$6^{+}$Cneorum tricoccum $\mathrm{L}$.}

This is the first count of a representative of the family Cneoraceae. This family consists of two genera with three species in the Mediterranean region, the Canaries, and Cuba (LANJouw 1968). Its taxonomic position is not clear. On the basis of anatomical characters WETTSTEIN (1935) assumed a close relationship with the Zygophyllaceae. It differs from this family by the presence of oil containing cells in bark and leaves, the absence of stipules and staminal appendices and by the arrangement of the stamens in a single whorl (HeGI 1965). Furthermore, the spectrum of the phenoles of the Cneoraceae does not support the incorporation of this family in the Geraniales as advocated by Wettstein (HEGNAUER 1964). HUTCHINSON (1959) assumed relationship with the Celastrales, whereas TakHTAJAN (1959) placed the family near the Rutales. Takhtajan's view is supported by the chromosome number $2 n=36$. 


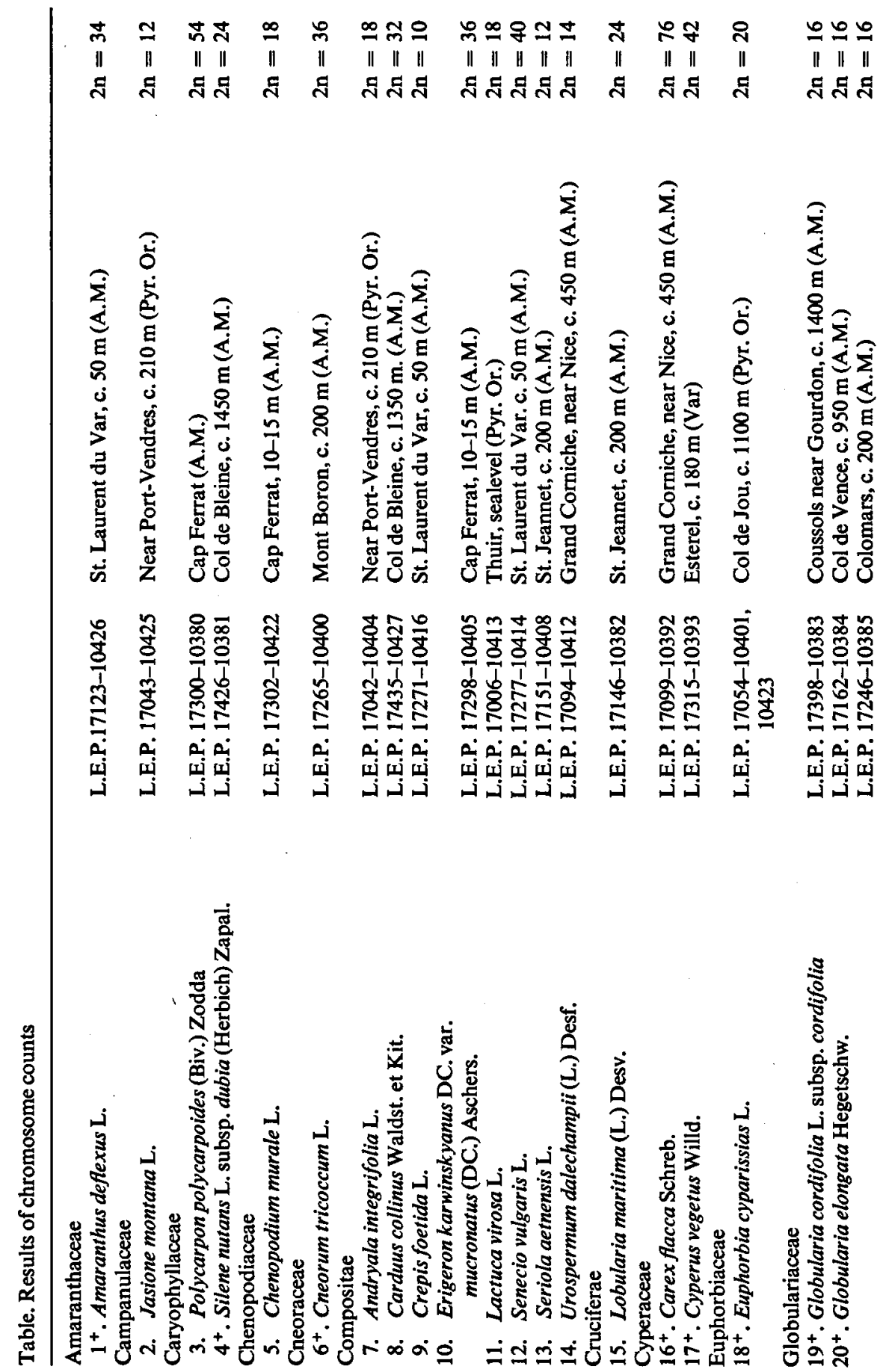


유유

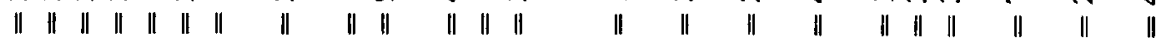

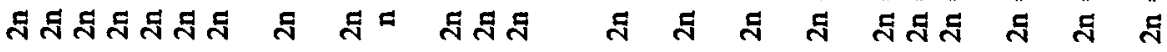

离

$\dot{\Sigma} \quad \dot{3}$

苍

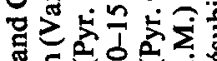

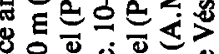

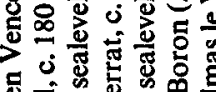

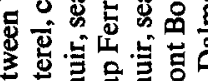

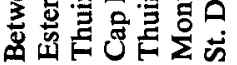

야을동

ชू

نं

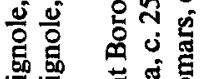

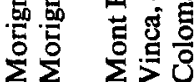

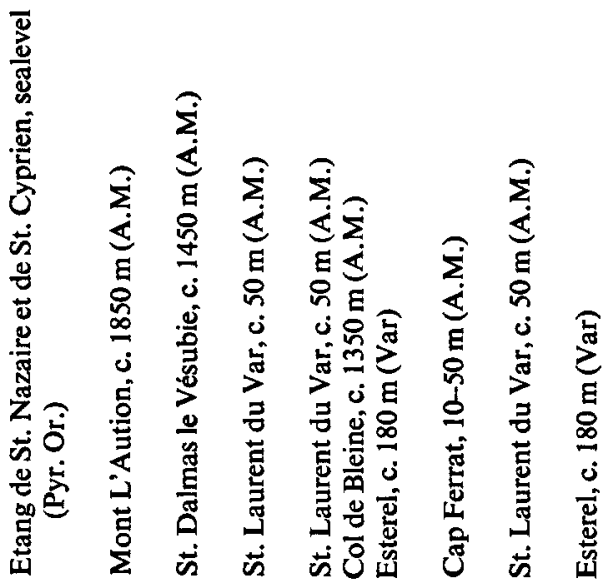

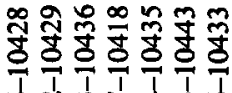

aิ

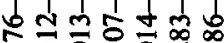

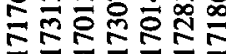

विंمिंمि

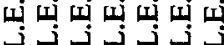



家守

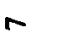

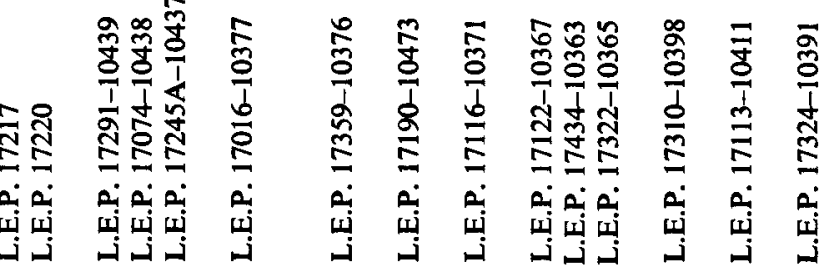
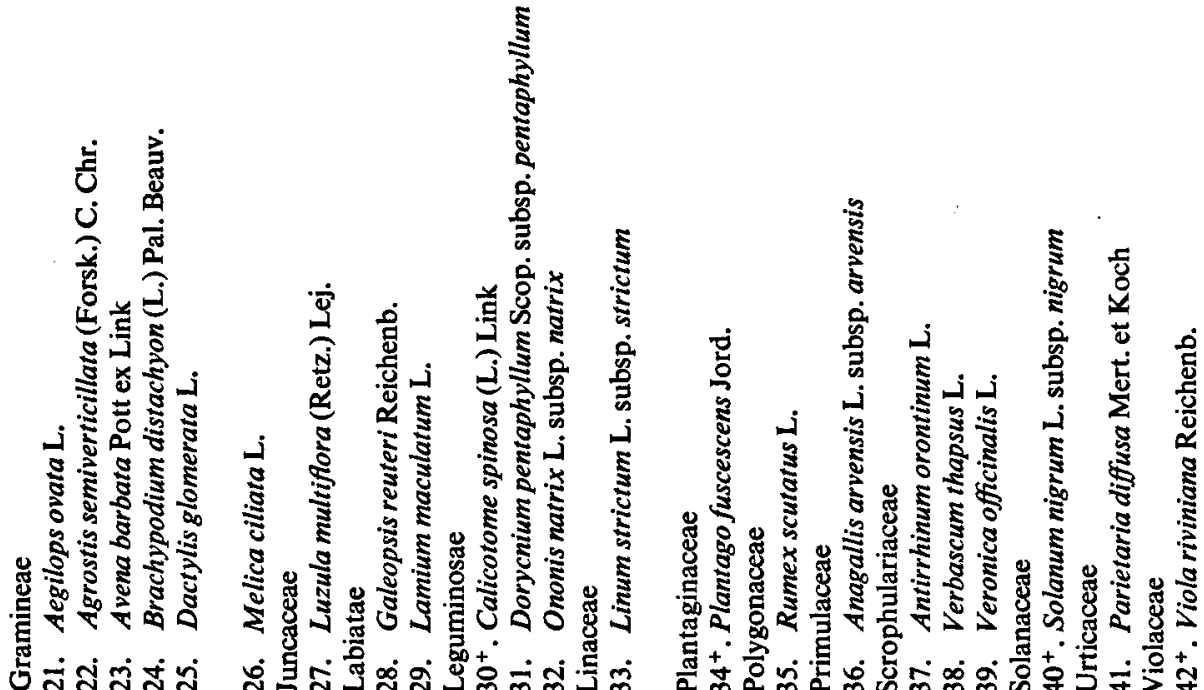


\section{$16^{+}$Carex flacca Schreb.}

The chromosome number $2 \mathrm{n}=76$ was also found in material from Scandinavia studied by HeILBORN $(1924,1932)$, from Iceland by LöVE \& LöVE (1956), and from Britain by Davies (1956 a, b). KJELLQVist \& LöVe (1963) reported $2 \mathrm{n}=90$ from plants from Spain $10 \mathrm{~km}$ South of Tagacete. It is of interest to notice that our material in cytological respect matches the plants from northern Europe.

\section{$17^{+}$Cyperus vegetus Willd.}

This species was introduced from South America and is now common in the South of France. It had not been studied cytologically before. The material investigated showed the number $2 n=42$.

\section{$18^{+}$Euphorbia cyparissias $\mathrm{L}$.}

In this species diploids $(2 n=20)$ and tetraploids $(2 n=40)$ are known. The distribution of the two cytotypes seems to be of interest at least in Europe (in America this species was introduced as a weed). The number $2 n=20$ found in our plants seems to support the opinion that tetraploids have a more eastern distribution as suggested by BAUER (1971), though PrITCHARd (1959) claimed the occurrence of tetraploids in England.

\section{$19^{+}$Globularia cordifolia L. subsp. cordifolia}

The specimen from Caussols near Gourdon (Alpes-Maritimes) has spatulate leaves with a tridentate apex. This is a character of the subspecies cordifolia (LARSEN 1957). Our plant is a diploid with $2 n=16$ chromosomes. Larsen (l.c.) reported $2 n=32$ for plants from France and Switzerland. Later ScHWARZ (1963) in a study of the entire genus Globularia confirmed the number $2 \mathrm{n}=32$ and besides also counted $2 n=48$. Further cytotaxonomic investigation within this polymorphic species complex seems to be worthwhile.

$20^{+}$Globularia elongata Hegetschw.

The number $2 n=16$ has also been reported by ScHWARz (1963) from material of unknown origin and by LöVE \& LöVE (1944) in plants from the neighbourhood of Lund in Sweden. However, the origin of these plants is uncertain because in Sweden Globularia elongata is only known from the islands Oland and Gotland and plants from Oland turned out to be tetraploids $(2 n=32)$ (LARSEN 1957). In the same paper the latter author reported also tetraploids from Spain. The distribution of the two cytotypes is unknown and needs further investigation.

\section{$30^{+}$Calicotome spinosa (L.) Link}

Our material proved to be a tetraploid with $2 n=48$ chromosomes. Up till now only diploids were known (GiLOT 1965). The chromosome number $2 \mathrm{n}=$ 48 is the same as in the other European species, C. villosa (Poiret) Link, which is morphologically clearly distinct from $C$. spinosa Link.

\section{$34^{+}$Plantago fuscescens Jord.}

In a study of the chromosomes and their morphology in the Plantaginaceae McCullagh (1934) reported $2 \mathrm{n}=24$ for $P$. fuscescens Jord. The number $2 \mathrm{n}=$ 
36 found in our study is in agreement with the observation of RESENDE (1937). According to LöVE \& LöVE (1961) the Plantaginaceae show the basic numbers $x=5$ and $x=6$. The species investigated belongs to the series with $x=6$ and polyploidy obviously occurs. No correlation between cytotype and morphology has been established. This needs further investigation.

\section{$40^{+}$Solanum nigrum $\mathrm{L}$.}

In this cosmopolitan species a large series of polyploids occurs. Up till now the chromosome numbers $2 \mathrm{n}=24,48,72,96$, and 144 are known. The hexaploid is the most common and in Europa the normal representative. According to LöVE \& LöVE (1961) this cytotype is to be regarded as subspecies nigrum.

$42+$ Viola riviniana Reichenb.

Viola riviniana Reichenb. is a polymorphic species characterized by intraspecific aneuploidy [ $2 \mathrm{n}=35,40,46$, and 47 (VALENTINE 1949; GADELLA 1963; GADELLA \& KLIPHUIS 1963)]. There is, however, no correlation between the differences in morphology and the differences in chromosome number (Gadella 1.c.). $V$. riviniana Reichenb. and $V$. reichenbachiana Jord. ex Bor. were formerly considered to be varieties of $V$. silvatica Fr., but several morphological characters permit to distinguish two separate species. Apart from the diagnostic differences, $V$. riviniana and $V$. reichenbachiana have also different levels of polyploidy, $V$. reichenbachiana being diploid $(2 n=20)$ and $V$. riviniana tetraploid $(2 n=40)$.

\section{ACKNOWLEDGEMENTS}

The authors wish to express their gratitude to Prof. Dr. G. Lapraz, Nice, and Dr. A. Cauwet, Perpignan, for providing hospitality at their Institutes and homes and kind assistance in many other ways to the junior author during the summer of 1970 . The authors are much indebted to Mrs. I. Belfroid - van der Lem for her assistance in determining the material studied, and to Mr. L. Y. Th. Westra for his linguistic advice.

\section{REFERENCES}

BAUER, Z. (1971): Karyological studies in the genus Euphorbia L. II. Acta Biol. Crac. XIV: $159-178$.

DAVIES, E. W. (1956a): Cytology, evolution and origin of the aneuploid series in the genus Carex. Hereditas 42 (3-4): 349-366.

- (1956b): Some new chromosome numbers in the Cyperaceae. Watsonia 3: 242-243.

Gadella, Th. W. J. (1963): A cytotaxonomic study of Viola in the Netherlands. Acta Bot. Neerl. 12: 17-39.

-, \& E. KuIPHUIS (1963): Chromosome numbers of flowering plants in the Netherlands $I$. Acta Bot. Neerl. 12: 195-230.

GiLor, J. (1965): Contribution à l'étude cytotaxinomique des Genisteae et des Loteae. Cellule 65: 317-347.

Grant, W. F. (1959): Cytogenetic studies in Amaranthus III. Chromosome numbers and phylogenetic aspects. Can. Journ. Gen. Cytol. 1: 313-328.

HegI, G. (1965): Illustrierte Flora von Mitteleuropa. C. Hanser Verlag, München.

Hegnauer, R. (1964): Chemotaxonomie der Pfanzen 3. Birkhäuser Verlag, Basel/Stuttgart. 
HeIlborn, O. (1924): Chromosome numbers and dimensions, species formation and phylogeny in the genus Carex. Hereditas 5: 129-216.

- (1932): Aneuploidy and polyploidy in Carex. Svensk Bot. Tidskr. 26: 137-146.

HuTCHInson, J. (1959): The families of flowering plants I. Clarendon Press, Oxford.

KJellqvist, E. \& Löve A. (1963): Chromosome numbers of some Carex species from Spain. Bot. Notis. 116: 241-248.

Lanjouw, J. \& CollaB. (1968): Compendium van de Pteridophyta en Spermatophyta. Oosthoek, Utrecht.

LARSEN, K. (1957): Cytological observations on some species of Globularia. Bot. Notis 110: 265-270.

LÖVE, A. \& D. LöVE, (1944): Cytotaxonomic studies on boreal plants III, some new chromosome numbers in Scandinavian plants. Arkiv Bot. 31 A: 1-22.

- \& -, (1956): Cytotaxonomical conspectus of the Icelandic Flora. Acta Horti Gothob. 20: 65-291.

— \& -, (1961): Chromosome numbers of Central and North-West European plant species. Opera Botanica (Lund) 5: 1-581.

MCCUllaGH, D. (1934): Chromosome and chromosome morphology in the Plantaginaceae I. Genetica 16: 1-44.

Pritchard, T. O. (1959): Cytotaxonomy and ecology of the weedy species Euphorbia cyparissias L. and Euphorbia esula L. IX Int. Bot. Congr. Vol. II Abstr. 311.

RESENDE, F. (1937): Uber die Ubiquität der SAT-Chromosomen bei den Blütenpflanzen. Planta 26: 757-807.

SCHWARz, O. (1963): Chromosomenzahlen, Lebensformen und Evolution der Gattung Globularia L. Drudea III: 5-16.

TAKHTAJAN, A. (1959): Die Evolution der Angiospermen. Gustav Fischer, Jena.

VALENTINE, D. H. (1949): Vegetative and cytological variation in Viola riviniana Reichenb. Rept. Conf. Bot. Soc. British Isles 1949: 48-53.

WETTSTEIN, R. (1935): Handbuch der systematischen Botanik. Deuticke, Leipzig/Wien. 